\title{
Ecological risk analysis in marine fish farming: a case study of a seabass (Dicentrarchus labrax) farm located in Moroccan Mediterranean coast
}

\author{
Hassan NHHALA ${ }^{1,4, *}$, Abdeljallil BAHIDA ${ }^{4}$, Imane NHHALA ${ }^{4}$, Housni CHADLI ${ }^{5}$, \\ Azeddine ABREHOUCH ${ }^{1}$, Benyounes ABDELLAOUI ${ }^{3}$, Mohamed ID HALLA ${ }^{2}$ and \\ Hassan ER-RAIOUI ${ }^{4}$ \\ ${ }^{1}$ National Institute of Fisheries Research (INRH), Aquaculture Centre, M'diq, Morocco (Former \\ researcher). \\ ${ }^{2}$ National Institute of Fisheries Research (INRH), Department of Aquaculture, Casablanca, Morocco. \\ ${ }^{3}$ National Institute of Fisheries Research (INRH), Regional Centre, Tangier, Morocco. \\ ${ }^{4}$ Faculty of Sciences and Technics, University of Abdelmalek Essaadi, Tangier, Morocco. \\ ${ }^{5}$ Marine Fish Farm « Aquam'diq », M'diq, Morocco.
}

\begin{abstract}
The present study aimed at studying ecological interaction between a fish farm cages located in M'diq bay, in western Moroccan Mediterranean coast, and its local environment. It was carried out in 2013 and 2016 through seabed analysis in terms of organic matter and some nutrients parameters such as Nitrogen and Phosphorus, as well as through monitoring macro-fauna assemblages. The results showed recorded values relatively stable in three years' interval and have a well-integrated fish farming activity within its ecosystem. Sediment was sandy to sandy shelly types and macro-benthic fauna were composed of six groups, Gastropods, Bivalves, Scaphopoda, Amphipods, Nematoda and Polychaeta. Organic matter and Total Organic Carbon were respectively less than 3.2\% and $1.87 \%$ and very low comparing with others Mediterranean fish farms sites. Estimation of Nitrogen, Phosphorus and Carbon potential releases of M'diq fish farm gave low data related to its production capacity not exceeding 200 tons by year. Influenced with open sea location and high current state, dispersion pattern of these fish farm discharges seemed to play a key role in keeping lower values. ANOVA analysis showed no significant difference between studied parameters in the five sampling stations comparing with the reference station both on geographical and temporal levels (seasons and years).
\end{abstract}

\section{Introduction}

The development of aquaculture production is related to consumers' perception, knowing that aquaculture products are registering a higher growth ratio, almost $5.41 \%$ per year $(3.02$ million tons/year) [1]. Consumers' perception is depending on many criteria $[2,3]$ among

*Corresponding author: nhhalahassan@yahoo.fr 
which the durability of aquaculture, relating to potential massive impacts on the environment, is the dominate negative perception of coastal community. As [4] reported, fish farming was, and still is, viewed as a potential polluter of the marine environment.

In marine fish farming, the main environmental impact is widely thought to be coming from organic matter discharges, resulted from cultured species metabolism (faeces, pseudofaeces, excretion...) and uneaten food (likely generated by excessive distribution of food or driven away by current). The abundance of organic matter discharges may create a change in chemical and physical characteristics of the environment and may have a potential effect on the biological chain composition of the receiving environment. Then, seabed could represent a memory reflecting the effect of anthropic activities on the environment. Seabed sediment is characterised by variable granulometry and physico-chemistry patterns depending on geomorphological and hydrodynamic conditions and by holding a multitude of benthic species. For these reasons, it could be considered as a mirror providing information on the local environment health state. Therefore, impacts are clearer on the seabed sediment composition [5-13].

In Morocco, even if marine aquaculture activity has started in fifties, mainly with marine shellfish culture, namely in Oualidia lagoon (in Atlantic coast), marine fish farming has only begun in 1986, in Nador lagoon situated in Mediterranean coast [14]. The first established fish farm in this lagoon was producing two fish species (Gilthead seabream, Sparus aurata, and European seabass, Dicentrarchus labrax). Since then, three others marine fish farms have been also established in Moroccan Mediterranean coast, one in 1991 in its Eastern part and the two others in 1998, in its Western part. They have been all growing seabream and seabass and selling them in the European market.

Moroccan fish farms were not so competitive than European ones; seabass and seabream produced by European farms were sold at low prices [15] in comparison with the ones produced by Moroccan farms. Due to difficulties in selling their cultured fishes in local markets, Moroccan farms have faced a critical situation leading to the activity cessation of three of the fourth existing marine fish farms.

Since then, only one marine fish farm is still operating in Morocco. It is located in its Western part of its Mediterranean coast, in M'diq Bay. This farm has been well adapted to the national context market through creating its own cultured fish marketing network. Moreover, it has been concerned by its environmental farm consideration to be able to sustain its activity. Indeed, Moroccan legislation has settled up, in 2003, measures for environmental aquaculture farms monitoring based on results of the environmental impact study. The implementation of this monitoring has become mandatory. The purpose is to ensure sustainability and proper local integration of aquaculture activity with respect to local environment conditions.

The present study was conducted in this context, in join cooperation with the M'diq fish farm, the Aquaculture Centre of the National Institute of Fisheries Research (INRH) in M'diq and the Scientific and Technical Faculty of Abdelmalek Essaâdi University in Tangier. Knowing that aquaculture activities are depending on its local environment conditions to develop and persevere, the present work focuses on some sensitive parameters which are used in ecological approach to assess aquaculture impacts. So, the main objective is to characterise the current situation of the interaction between the said fish farm and its culture site environment and to evaluate ecological risks associated with the fish farming activity through some pertinent geochemical and biological parameters (nitrogen, phosphorus, total organic carbon and macro-benthos), providing information on potential impacts on local and surrounding area, particularly on sediment and benthos. 


\section{Materials and methods}

\subsection{Study area}

The study area is located in M'diq bay, in the north-western part of Morocco, particularly in western part of its Mediterranean coast (Figure 1). It is situated between Sebta Cap in the north $\left(35^{\circ} 54^{\prime} \mathrm{N}, 5^{\circ} 17^{\prime} 10^{\prime \prime} \mathrm{W}\right)$ and Negro Cap in the south $\left(35^{\circ} 40^{\prime} \mathrm{N}, 5^{\circ} 16^{\prime} 40^{\prime \prime} \mathrm{W}\right)$. It has $23 \mathrm{~km}$ in length and $130 \mathrm{~km}^{2}$ in surface area.

This bay is bounded by Rif mountain chain in the west and opened towards to the East. The hinterland is represented by a large watershed, situated between the sea (the bay) and the mountain chain, generating during the winter a great flow and runoff of the rainy waters, led by two main rivers (Smir river and Negro river) [16, 17].

The hydrodynamic characteristics of this bay can be summarized as follows:

- The tide is semi-diurnal;

- The mean tidal range at spring tide is of 0.8 to $1 \mathrm{~m}[18]$;

- The swell direction is from East to North-East, generated by local winds;

- The coastal current is dominant and bears Southeast and the offshore current bears East. The tidal current direction is northwest at the swell tide and south-east at the ebb tide [19].

The fish farm culture facility is composed of 14 circular Polyethylene high-density floating cages. They have each $12 \mathrm{~m}$ in diameter and $10 \mathrm{~m}$ in net depth (with approximately $1,100 \mathrm{~m} 3$ in rearing volume). Cages are set on a bathymetry range of 18 and $22 \mathrm{~m}$. Farming site extends over an area of $5.2 \mathrm{ha}$, located $2.3 \mathrm{~km}$ east of the $\mathrm{M}^{\prime}$ diq beach $\left(35^{\circ} 41^{\prime} 16.3^{\prime \prime} \mathrm{N}\right.$, $\left.5^{\circ} 19^{\prime} 23.1 \mathrm{~W}\right)$. The annual fish capacity production of this farm is reaching approximatively 200 tons. The cultured fish is seabass and it is fed manually every day on conventional extruded commercial diets.

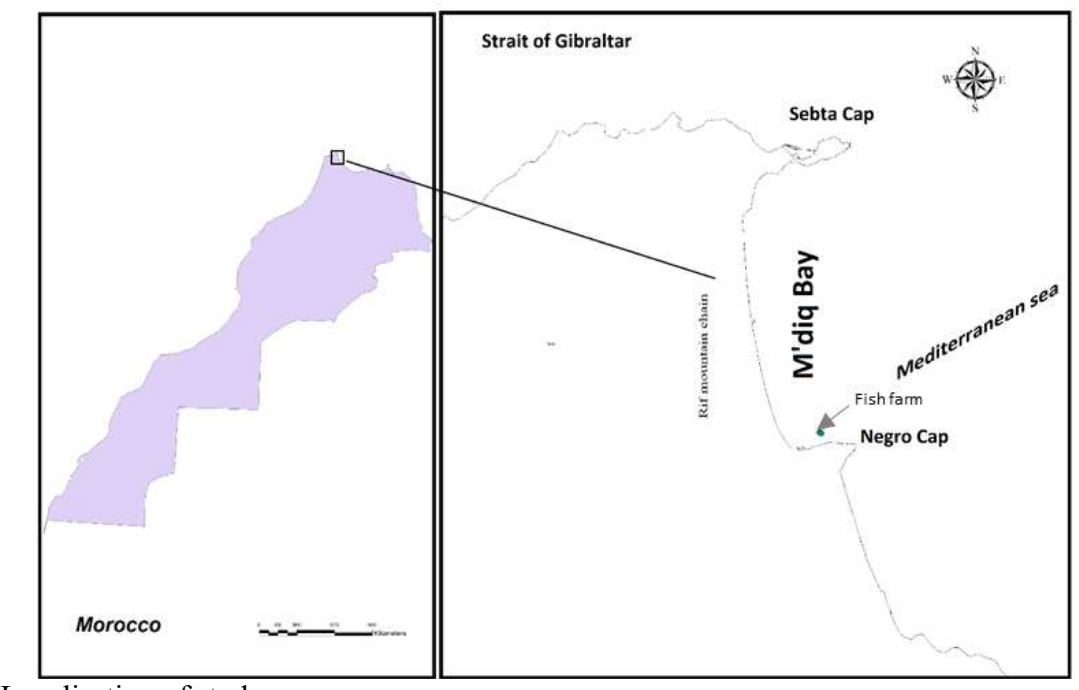

Fig. 1. Localisation of study area.

\subsection{Water column investigation}

Main oceanographic parameters investigated in fish farm water column are dissolved oxygen, $\mathrm{pH}$, temperature and salinity. They were measured in-situ (field data) using a portable multi-parameter (ELMETRON, CX-401; WTW, Multi 340i). Remote sensing data 
(satellite data) was also collected by using satellite imagery. A statistical correlation test was performed on field data and satellite data and it has shown an important correlation coefficient $(\mathrm{R}=0.76)$ between them. Nitrate $\left(\mathrm{NO}_{3}\right)$ and Phosphate $\left(\mathrm{PO}_{4}\right)$ were measured through seawater sampling which were first frozen and then analysed later according to the experimental protocols described by [20] and compared with their satellite data. Therefore, and basing on the important correlation coefficient field data and satellite data, only the latter were employed in this study because of their availability for all the year round. Chlorophyll-a data was only collected using Remote sensing for each station position. Field data were measured during six times in 2013 and same in 2016 while satellite data were collected once a week in each month along each year of 2013 and 2016.

\subsection{Sediment sampling strategy}

Sediment sampling (Table 1) was performed in 2013 and 2016 based on the following strategy. Sampling stations number has been set at six falling into three following categories: one station located in the central point of the cages (Central Station (S-C)), four stations located each in of one of the fourth edges of the farm's site (designated as S-1, S-2, S-3 and S-4) and the last one is located outside of the farm's site at a distance of about 500 $\mathrm{m}$ from its limit and considered as a reference Station (S-R) (Figure 2). The latter station was selected in an offshore area, within a depth and bottom type comparable to the two site's farm edges stations oriented towards open sea (S-2 and S-3). In similar study, particularly in Turkey [21], Greece [22] and Italy [23], reference stations were respectively set at 500-700 $\mathrm{m}$ and $300 \mathrm{~m}$ and $900 \mathrm{~m}$ away from fish farming farms locations.

Table 1. Geographical coordinates and depths of sampling stations.

\begin{tabular}{|c|c|c|c|}
\hline Sampling Station & Depth (m) & Latitude (N) & Longitude (E) \\
\hline S-1 & 19.2 & 35.690314 & -5.296541 \\
\hline S-2 & 21.7 & 35.691611 & -5.297545 \\
\hline S-3 & 21.2 & 35.691228 & -5.298485 \\
\hline S-4 & 18.8 & 35.689961 & -5.297382 \\
\hline S-C & 20.8 & 35.690811 & -5.297404 \\
\hline S-R & 23.5 & 35.695463 & -5.295067 \\
\hline
\end{tabular}

Sampling operations are each based on three replicates taken from each sampling station. They were carried out with a small and a little bit heavier Van Veen grab (fitted with weighting blocks). Its sampling surface area is of $250 \mathrm{~cm}^{2}$. The mode of its operation to retrieve sediment samples is very easy. It is composed of two jaws which are kept opened by a hook, just before sampling. Then, the grab is steadily and carefully sunk in the sea. Both jaws are fitted with holes allowing air to escape during the sinking. As soon as the jaws touch the bottom, the hook loosens its grip and when hoisting the rope, the jaws shut tight because of the leverage by the rods. The drawn sample amount depends mainly on the nature and the compactness of the sea bottom. However, this heavier grab catches more sediment than another lighter one that has been locally tested. Once surfaced, the grab is emptied and cleaned before being reused.

Moreover, in spite of the heavy closing force, it sometimes happened that a pebble was caught between the buckets. In such case, the sample was not considered because it could not be representative; the smaller parts of sediment might have been lost during hoisting. Then, the sampling operation is systematically repeated. 


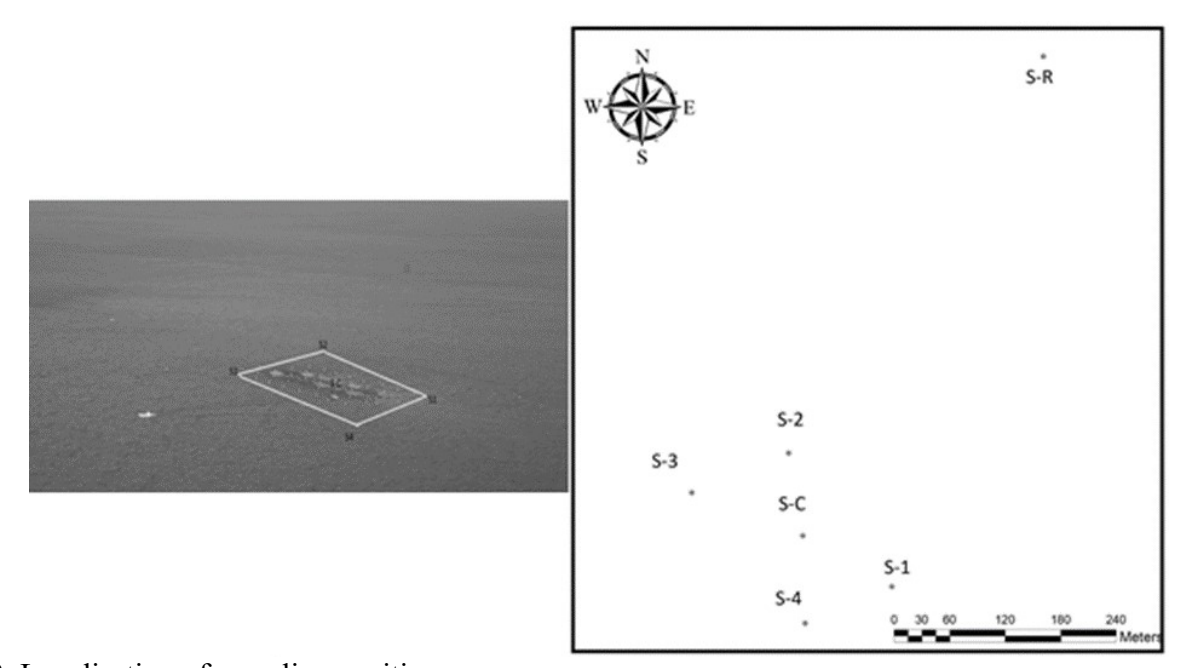

Fig. 2. Localisation of sampling position.

\subsection{Sediment grains sizes}

Granulometric sediment study was carried out on the six sampling stations. Granulometric characterization was performed applying the international classification used in geology for which Bellair and Pomerol have proposed a simplified terminology [24]. This classification provides three categories of particles according to their size: Rudite "gravels" $(<2 \mathrm{~mm})$, Arenite "Sand" (between 2 and $0.063 \mathrm{~mm})$ and Lutite "silts and clays" $(<0.063 \mathrm{~mm})$.

\subsection{Organic Matter (OM) and Total Organic Carbon (TOC) in sediment}

Two different methodologies of assessing TOC in sediment were used both in 2013 and 2016. The first method dealt with Organic matter measuring using the ignition loss method (at $475-500^{\circ} \mathrm{C}$ ). Samples were first sieved to remove particles sizes over $2 \mathrm{~mm}$ and then, the remaining grains sizes, lower than $2 \mathrm{~mm}$, were subjected to calcination in an electric furnace in order to create optimal condition for total oxidation of organic matter, destruction of carbonates and elimination of a maximum of inter-foliar water and water of the clay borders. Organic matter is further expressed as a percentage of the sample mass during the first heating at $220^{\circ} \mathrm{C}\left(\mathrm{M}_{1}\right)$ and the second heating at $450^{\circ} \mathrm{C}\left(\mathrm{M}_{2}\right)$ and the initial weight of the crucibles $\left(\mathrm{M}_{0}\right)$ :

$$
\operatorname{OM}(\%)=\left(M_{1}-M_{2}\right) /\left(M_{1}-M_{0}\right) \times 100
$$

The second method was based on Walkley and Black [25] wet oxidation method. Organic matter was determined in sediment as follows: first allows to evaluate the TOC and then calculate OM percentage using the following approximation formula:

$$
\% O M=\% C \times 1.72
$$

\subsection{Sediment Nitrogen and Phosphorus}

Nitrogen and Phosphorus measurements in sediment were also both subjected to two different analysis methods in 2013 and 2016. Total Phosphorus was measured by the Dabinmodified Method [26] and by the scanning electron microscopy analysis. 
Total Nitrogen was performed by Colorimetric Methods and also by the scanning electron microscopy analysis.

\subsection{Potential chemical elements release}

In order to have, on an indicative basis, an idea about the potential Carbon, Nitrogen and Phosphorus fluxes produced by the cultured fish stock in the studied farm, an estimation of total discharges of these chemical elements (resulted from mineralization of uneaten feed and cultured fish faeces) have been made, based on results reported by [27]. These authors reported that 1 ton of produced seabass can generate $45 \mathrm{~kg}$ of carbon, $8 \mathrm{~kg}$ of Nitrogen and $0.3 \mathrm{~kg}$ of Phosphorus, released as faeces and $284 \mathrm{~kg}$ of Carbon, $45 \mathrm{~kg}$ of Nitrogen and $4 \mathrm{~kg}$ of Phosphorus realised as wasted feed.

Therefore, the produced fish biomass and the feeding quantity data were collected from the studied fish farm to estimate its potential Carbon, Nitrogen and Phosphorus fluxes, that could be produced local area in M'diq bay and likely deposed in its site seabed. For this, and taking into consideration local high hydrodynamic conditions (reaching a max of 1.1 $\mathrm{m} / \mathrm{s}$ ) and the seabed slop (about 2.2\%), potential chemical elements release have been estimated and expressed according first to the cages area and then to the exploited concession area. These latter have an area surface of 5,600 $\mathrm{m}^{2}$ and 52,000 $\mathrm{m}^{2}$ respectively.

\subsection{Macro-benthic data}

Ecological impacts of M'diq fish farm were assessed through macro-benthic variability assessment in sediment retrieved in beneath and surrounding area of fish cages. Samples of sediment were collected by scuba diving, using a circular piece of PCV pipe of $20 \mathrm{~cm}$ in diameter and $10 \mathrm{~cm}$ in height. Three replicates were operated in each of the same six sediment sampling stations. Collected sediment samples were first sieved through a $1 \mathrm{~mm}$ mesh and retained parts were checked for organisms visible to the naked eye. The smallest ones were kept in a petri dish filled with few seawater. They were examined under a magnifying glass, a profile projector or a stereomicroscope, depending on the organism size. Photos were taken for each kind of collected organisms. They were sorted and identified mainly by major groups. The total individuals number of each group was determined for each station's sample and reported in terms of abundances (Ind.) and percentages (\%) per $\mathrm{m}^{2}$ for each group in each sampling station in 2013 and 2016.

\subsection{Statistic data analysis}

Results of chemical, physical and biological water parameters obtained for each season and station position were statically analysed using one-way ANOVA analysis of variance. Statistical significant differences $(\mathrm{P}<0.05)$ between stations position and sampling years were performed following ANOVA Test for organic matter (OM), Total organic Carbone (TOC), Nitrogen (N) and Phosphorus (P). A Correlation Coefficient Test was also applied for parameters water column: Chlorophyll-a (Chl-a), Temperature $(\mathrm{T})$, Nitrate $\left(\mathrm{NO}_{3}\right)$, Phosphate $\left(\mathrm{PO}_{4}\right)$, potential of Hydrogen $(\mathrm{pH})$, Salinity $(\mathrm{S})$ and dissolved Oxygen (Oxy).

Also, significant changes in macro-benthic community were assessed between sampling stations and sampling years, using one-way ANOVA analysis of variance in terms of each group of organisms and organisms' numbers found in 2013 and 2016. 


\section{Results}

\subsection{Seawater column parameters measurements}

Biological, chemical and physical seawater parameters were calculated for the two samplings years, 2013 and 2016. Data are presented according to seasons (Table 2). A significant difference $(\mathrm{P}<0.001)$ was found between seasons while non-significant difference was found between sampling stations (Table 3). This result can be explained by the importance of the local hydrodynamic leading a well renewal and mixing of waters and the great capacity of water flushing of this opened bay allowing dilution and dispersion of fish farm discharges. The local current speed can reach a maximum $1.1 \mathrm{~m} / \mathrm{s}$ coming from the SW and the NE (source: SIMAR buoy) with a respective frequency of $10 \%$ and $8 \%$ per year since 1997 until 2016.

Table 4 shows a matrix of correlation coefficients, determining relation between seawater column parameters. Negative correlations were found between Temperature and dissolved Oxygen $(\mathrm{R}=-0.89), \mathrm{pH}(\mathrm{R}=-0.90)$, phosphorus $(\mathrm{R}=-0.61)$ and $\mathrm{Chl}-\mathrm{a}(\mathrm{R}=-0.65)$ in 2013 and 2016 samples. In the other hand, an important positive correlation was found between dissolved oxygen and $\mathrm{pH}(\mathrm{R}=0.92)$, nitrate and phosphorus $(\mathrm{R}=0.89)$ and phosphorus and Chl-a $(\mathrm{R}=0.78)$.

Table 2. Results of sampling stations parameters (Mean \pm standard error, Minimum and Maximum).

\begin{tabular}{|c|c|c|c|c|c|}
\cline { 2 - 6 } \multicolumn{1}{c|}{} & Winter & Spring & Summer & Autumn & $\begin{array}{c}\text { Range } \\
\text { (max-min) }\end{array}$ \\
\hline $\mathrm{Chl-a} \mathrm{(mg/l)}$ & $0.569 \pm 0.162$ & $0.289 \pm 0.138$ & $0.168 \pm 0.060$ & $0.406 \pm 0.151$ & $0.776-0.115$ \\
\hline $\mathrm{NO}_{3}(\mathrm{mg} / \mathrm{l})$ & $0.017 \pm 0.014$ & $0.004 \pm 0.002$ & $0.003 \pm 0.001$ & $0.017 \pm 0.011$ & $0.049-0.002$ \\
\hline $\mathrm{PO}_{4}(\mathrm{mg} / \mathrm{l})$ & $0.012 \pm 0.003$ & $0.004 \pm 0.002$ & $0.002 \pm 0.000$ & $0.009 \pm 0.004$ & $0.017-0.002$ \\
\hline $\mathrm{pH}$ & $8.097 \pm 0.013$ & $8.082 \pm 0.025$ & $8.028 \pm 0.017$ & $8.072 \pm 0.008$ & $8.200-8.000$ \\
\hline $\mathrm{Oxy}(\mathrm{mg} / \mathrm{l})$ & $7.836 \pm 0.153$ & $7.784 \pm 0.232$ & $7.237 \pm 0.177$ & $7.540 \pm 0.162$ & $8.120-6.930$ \\
\hline $\mathrm{S}(\%)$ & $36.287 \pm 0.071$ & $36.152 \pm 0.023$ & $36.235 \pm 0.042$ & $36.221 \pm 0.036$ & $36.400-36.000$ \\
\hline $\mathrm{T}\left({ }^{\circ} \mathrm{C}\right)$ & $16.482 \pm 0.730$ & $17.309 \pm 1.079$ & $20.373 \pm 0.947$ & $18.014 \pm 0.727$ & $22.600-15.500$ \\
\hline
\end{tabular}

Table 3. Values of one-way analysis of variance for water column measurement.

\begin{tabular}{|c|c|c|c|c|c|c|}
\hline & \multicolumn{3}{|c|}{ Stations } & \multicolumn{3}{|c|}{ Seasons } \\
\hline & d.f. & $\mathrm{F}$ & P Level & d.f. & $\mathrm{F}$ & P Level \\
\hline Chl-a (mg/l) & 5 & 0.0005 & Ns & 3 & 87.8712 & $* * *$ \\
\hline $\mathrm{NO}_{3}(\mathrm{mg} / \mathrm{l})$ & 5 & 0.0001 & Ns & 3 & 20.9992 & $* * *$ \\
\hline $\mathrm{PO}_{4}(\mathrm{mg} / \mathrm{l})$ & 5 & 0.0000 & Ns & 3 & 68.9110 & $* * *$ \\
\hline pH & 5 & 0.0000 & $\mathrm{Ns}$ & 3 & 165.6104 & $* * *$ \\
\hline Oxy (mg/l) & 5 & 0.0001 & Ns & 3 & 120.2864 & $* * *$ \\
\hline S (\%o) & 5 & 0.0002 & Ns & 3 & 76.9153 & $* * *$ \\
\hline $\mathbf{T}\left({ }^{\circ} \mathbf{C}\right)$ & 5 & 0.3532 & Ns & 3 & 317.7456 & $* * *$ \\
\hline
\end{tabular}


Table 4. Correlation coefficients matrix between seawater column parameters.

\begin{tabular}{|c|c|c|c|c|c|c|c|}
\cline { 2 - 8 } \multicolumn{1}{c|}{} & $\mathbf{T}$ & $\mathbf{O x y}$ & $\mathbf{p H}$ & $\mathbf{S}$ & $\mathbf{N O}_{\mathbf{3}}$ & $\mathbf{P O}_{\mathbf{4}}$ & $\mathbf{C h l - a}$ \\
\hline $\mathbf{T}$ & 1.00 & & & & & & \\
\hline $\mathbf{O x y}$ & -0.89 & 1.00 & & & & & \\
\hline $\mathbf{p H}$ & -0.90 & 0.92 & 1.00 & & & & \\
\hline $\mathbf{S}$ & -0.42 & 0.32 & 0.45 & 1.00 & & & \\
\hline $\mathbf{N O}_{\mathbf{3}}$ & -0.36 & 0.25 & 0.30 & 0.47 & 1.00 & & \\
\hline $\mathbf{P O}_{\mathbf{4}}$ & -0.61 & 0.52 & 0.57 & 0.66 & 0.89 & 1.00 & \\
\hline $\mathbf{C h l - a}$ & -0.65 & 0.67 & 0.68 & 0.58 & 0.53 & 0.78 & 1.00 \\
\hline
\end{tabular}

\subsection{Seawater column parameters measurements}

Granulometry analysis shows that all sampling stations are characterised by high percentages of the Arenite "Sand" fraction (between 2 and $0.063 \mathrm{~mm}$ ) with values ranging between $66 \%$ and $99 \%$ and very low values of Silts and Clays $(<63 \mu \mathrm{m})$ ranging between $0.42 \%$ and $4.32 \%$ (Table 5). Moreover, the six sampling stations could be divided in two different groups, one assembling the three stations situated toward offshore (S-R, S-2 and S-3; designated as offshore stations) characterised by high gravels (and shells debris) contents, ranging between $17.35 \%$ and $32.34 \%$ and the other gathering the three others stations, situated toward the coastal shore, (S-1, S-4 and S-C; designated as coastal stations), characterised by high sand contents ranging between $90.75 \%$ and $99.09 \%$.So, the offshore stations have a sandy shelly type sediment while the coastal stations have a sandy type sediment.

Table 5. Particles sizes distribution in the six sampling stations.

\begin{tabular}{|c|c|c|c|}
\hline \multirow{2}{*}{ Stations } & Gravels & Sand & Silts \&Clays \\
\cline { 2 - 4 } & $\mathbf{2} \mathbf{~ m m}$ & $\mathbf{2 ~} \mathbf{~ m m ~ - ~ 6 3 ~} \boldsymbol{\mu m}$ & $<\mathbf{6 3} \boldsymbol{\mu m}$ \\
\hline S-R & 32.34 & 66.50 & 1.16 \\
\hline S-1 & 0.16 & 99.09 & 0.69 \\
\hline S-2 & 23.88 & 75.35 & 0.76 \\
\hline S-3 & 17.35 & 81.82 & 0.83 \\
\hline S-4 & 0.34 & 95.33 & 4.32 \\
\hline S-C & 8.82 & 90.75 & 0.42 \\
\hline
\end{tabular}

\subsection{Chemical sediment parameters}

Results of chemical sediment parameters analysis are shown in Table 6. In 2013, the highest percentage of OM (2.58\%) was recorded in station S-3 while in 2016, a slight increase of $\mathrm{OM}$ was observed in all stations with a higher percentage recorded in station 4 $(3.2 \%)$.

Similar situation was recorded for TOC and Phosphorus and to a lesser extent for Nitrogen. In 2016, Station S-4 has relatively higher values in terms of OM, TOC, N and P comparing with the ones of the other five stations. However, statistical analysis, performed one-way ANOVA test (Table 7), showed that all parameters have a non-significate 
difference between the six stations (S-R, S-1, S-2, S-3, S-4 and S-C) and between the two study years (2013 and 2016).

Table 6. Analysis results of chemical sediment parameters obtained for 2013 and 2016 samples.

\begin{tabular}{|c|c|c|c|c|c|c|c|}
\hline Parameters & Year & S-R & S-1 & S-2 & S-3 & S-4 & S-C \\
\hline \multirow{2}{*}{ OM (\%) } & $\mathbf{2 0 1 3}$ & 0.90 & 1.00 & 2.50 & 2.58 & 0.96 & 1.20 \\
\cline { 2 - 8 } & $\mathbf{2 0 1 6}$ & 1.40 & 1.50 & 2.90 & 3.15 & 3.20 & 1.70 \\
\hline \multirow{2}{*}{ TOC (\%) } & $\mathbf{2 0 1 3}$ & 0.52 & 0.58 & 1.45 & 1.5 & 0.56 & 0.7 \\
\cline { 2 - 8 } & $\mathbf{2 0 1 6}$ & 0.84 & 0,86 & 1.75 & 1.85 & 1.87 & 1.00 \\
\hline \multirow{2}{*}{ Nitrogen (\%) } & $\mathbf{2 0 1 3}$ & 0.05 & 0.10 & 0.06 & 0.09 & 0.03 & 0.11 \\
\cline { 2 - 8 } & $\mathbf{2 0 1 6}$ & 0.00 & 0.00 & 0.72 & 0.42 & 2.83 & 0.07 \\
\hline \multirow{2}{*}{ Phosphorus (\%) } & $\mathbf{2 0 1 3}$ & $4.0 \times 10^{-3}$ & $3.2 \times 10^{-3}$ & $4.5 \times 10^{-3}$ & $4.9 \times 10^{-3}$ & $6.0 \times 10^{-3}$ & $6.2 \times 10^{-3}$ \\
\cline { 2 - 8 } & $\mathbf{2 0 1 6}$ & 0.04 & 0.00 & 0.06 & 0.04 & 0.29 & 0.5 \\
\hline
\end{tabular}

Table 7. Values of one-way analysis of variance for of chemical sediment parameters.

\begin{tabular}{|c|c|c|c|c|c|c|}
\cline { 2 - 7 } \multicolumn{1}{c|}{} & \multicolumn{3}{c|}{ Stations } & \multicolumn{3}{c|}{ Seasons } \\
\cline { 2 - 7 } \multicolumn{1}{c|}{} & d.f. & F & P Level & d.f. & F & P Level \\
\hline OM & 5 & 2.1416 & ns & 1 & 2.6961 & ns \\
\hline TOC & 5 & 2.1254 & ns & 1 & 2.8812 & ns \\
\hline Azote & 5 & 0.8216 & $\mathrm{~ns}$ & 1 & 1.7986 & $\mathrm{~ns}$ \\
\hline Phosphorus & 5 & 0.7275 & $\mathrm{~ns}$ & 1 & 3.3816 & $\mathrm{~ns}$ \\
\hline
\end{tabular}

\subsection{Potential chemical parameters release}

The studied farm is characterized by a monthly evolution in terms of cultured fish biomass, distributed amount of fish feed and site temperature as shown in Figure 3 related to the two sampling years (2013 and 2016).

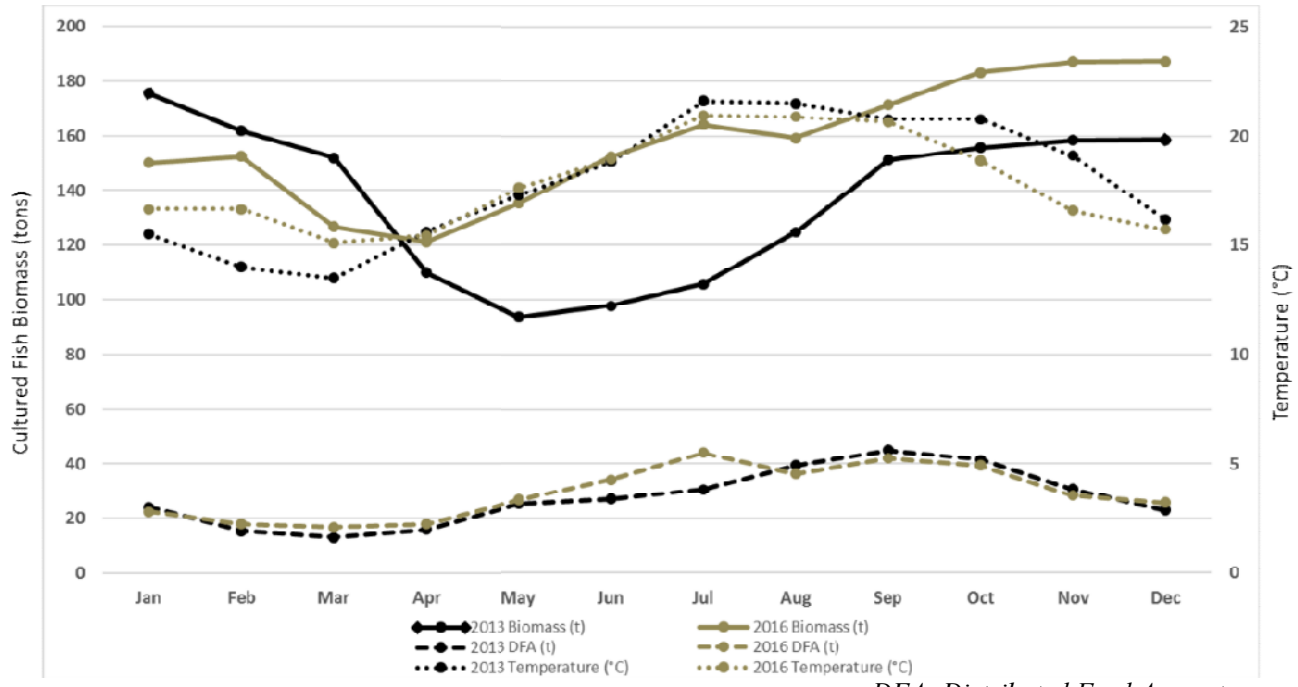

DFA: Distributed Feed Amount. 
Fig. 3. Monthly evolution of cultured seabass biomass production, distributed fish feed and site temperature in the two sampling years (2013 and 2016).

The monthly cultured fish biomass differences between 2013 and 2016 resulted mainly from differences in fish sales amounts and in fish biomass growth increase. The decreases in biomass curve (Figure 3) resulted from the balance between the output (fish sales amounts) which was higher than the input (fish biomass growth increase). The annual produced seabass was 137.06 tonnes in 2013 and 157.58 tonnes in 2016 with an annual distributed amount of feed much higher in 2016 than 2013 of 20.64 tonnes. The annual mean temperature was $17.9^{\circ} \mathrm{C}$ in 2013 and $17.8^{\circ} \mathrm{C}$ in 2016 .

Although these differences, statistical analysis (ANOVA test) showed that there is a non-significant difference in released carbon from faeces and wasted feed both in a cage surface $(\mathrm{P}<0.05$, d.f. $=1, \mathrm{~F}=0.1816)$ and in the concession surface $(\mathrm{P}<0.05$; d.f. $=1$; $\mathrm{F}=0.2153)$. The same result is obtained for Nitrogen $(\mathrm{P}<0.05 ;$ d.f. $=1 ; \mathrm{F}=0.1391)$ and Phosphorus $(\mathrm{P}<0.05 ;$ d.f. $=1 ; \mathrm{F}=0.0091)$.

Table 8. Values of one-way analysis of variance for of chemical sediment parameters.

\begin{tabular}{|c|c|c|c|c|c|c|c|}
\hline & Parameter & Year & $\begin{array}{c}\text { Mean } \\
\left(\mathrm{g} \cdot \mathrm{m}^{-2} \mathrm{~d}^{-1)}\right.\end{array}$ & & Parameter & Year & $\begin{array}{c}\text { Mean } \\
\left(\mathrm{g} \cdot \mathrm{m}^{-2} \mathrm{~d}^{-1)}\right.\end{array}$ \\
\hline \multirow{6}{*}{$\begin{array}{c}\text { Released as } \\
\text { faeces in the } \\
\text { exploited site } \\
\text { area }\end{array}$} & \multirow{2}{*}{$\mathrm{C}$} & 2013 & 3.240 & \multirow{6}{*}{$\begin{array}{l}\text { Released as faeces } \\
\text { in the concession } \\
\text { circumference } \\
\text { surface }\end{array}$} & \multirow[b]{2}{*}{$\mathrm{C}$} & 2013 & 0.349 \\
\hline & & 2016 & 3.442 & & & 2016 & 0.371 \\
\hline & \multirow{2}{*}{$\mathrm{N}$} & 2013 & 0.648 & & \multirow{2}{*}{$\mathrm{N}$} & 2013 & 0.070 \\
\hline & & 2016 & 0.688 & & & 2016 & 0.074 \\
\hline & \multirow{2}{*}{$\mathrm{P}$} & 2013 & 0.024 & & \multirow{2}{*}{$\mathrm{P}$} & 2013 & 0.003 \\
\hline & & 2016 & 0.026 & & & 2016 & 0.003 \\
\hline \multirow{6}{*}{$\begin{array}{l}\text { Released as } \\
\text { wasted feed in } \\
\text { the exploited } \\
\text { site area }\end{array}$} & \multirow{2}{*}{$\mathrm{C}$} & 2013 & 23.005 & \multirow{6}{*}{$\begin{array}{c}\text { Released as } \\
\text { wasted food in the } \\
\text { concession } \\
\text { circumference } \\
\text { surface }\end{array}$} & \multirow{2}{*}{$\mathrm{C}$} & 2013 & 2.477 \\
\hline & & 2016 & 24.438 & & & 2016 & 2.632 \\
\hline & \multirow{2}{*}{$\mathrm{N}$} & 2013 & 3.645 & & \multirow{2}{*}{$\mathrm{N}$} & 2013 & 0.393 \\
\hline & & 2016 & 3.872 & & & 2016 & 0.417 \\
\hline & \multirow[t]{2}{*}{$P$} & 2013 & 0.324 & & \multirow{2}{*}{$\mathrm{P}$} & 2013 & 0.035 \\
\hline & & 2016 & 0.344 & & & 2016 & 0.037 \\
\hline \multirow{6}{*}{$\begin{array}{l}\text { Total chemical } \\
\text { elements } \\
\text { released from } \\
\text { faeces and } \\
\text { wasted feed }\end{array}$} & \multirow{2}{*}{ C } & 2013 & 26.245 & \multirow{6}{*}{$\begin{array}{l}\text { The sum of the } \\
\text { chemical } \\
\text { parameters } \\
\text { Released from } \\
\text { faeces and wasted } \\
\text { food }\end{array}$} & \multirow[t]{2}{*}{$\mathrm{C}$} & 2013 & 2.826 \\
\hline & & 2016 & 27.880 & & & 2016 & 3.002 \\
\hline & \multirow{2}{*}{$\mathrm{N}$} & 2013 & 4.293 & & \multirow{2}{*}{$\mathrm{N}$} & 2013 & 0.462 \\
\hline & & 2016 & 4.561 & & & 2016 & 0.491 \\
\hline & \multirow{2}{*}{$\mathrm{P}$} & 2013 & 0.348 & & \multirow[b]{2}{*}{$\mathrm{P}$} & 2013 & 0.038 \\
\hline & & 2016 & 0.370 & & & 2016 & 0.040 \\
\hline
\end{tabular}

\subsection{Macro-benthic results}

A total of six macro-benthic groups were found (Gastropods, Bivalves, Scaphopoda Amphipods, Nematoda and Polychaeta) in almost all stations. In both sampling years (2013 and 2016), gastropod and polychaeta groups were generally more abundant than the other groups. Among the six macro-benthic groups, Gastropods were more abundant in Station 1 and station 4 while Polychaeta were having a slightly higher in abundance in S-R. In generally speaking, marco-benthic abundance in the different groups ranged between 64 and 350 individuals per $\mathrm{m}^{2}$ (Ind. $/ \mathrm{m}^{2}$ ) in 2013 and between 32 and 382 ind. $/ \mathrm{m}^{2}$ in 2016, with the exception of some macro-benthic groups (Scaphopoda and Bivalves) which are absent in some stations (S-2, S-3 and S-C) (Figure 4). Scaphopoda were absent in Station S-2 in 2013 while Bivalves were absent in S-3 in 2016. They were both absent in S-C as well as in 2013 than in 2016. The total number all groups individuals is ranged between $510 \mathrm{ind} . / \mathrm{m} 2$ in S-C and 1,019 ind. $/ \mathrm{m}^{2}$ in S-4 for 2013 and from 446 ind. $/ \mathrm{m}^{2}$ in S-C to 1,019 ind. $/ \mathrm{m}^{2}$ in S- 
4 for 2016 . The specific proportion in macro-benthic groups ranged from $7 \%$ to $37 \%$ in 2013 while it ranged $4 \%$ and $43 \%$ in 2016 .

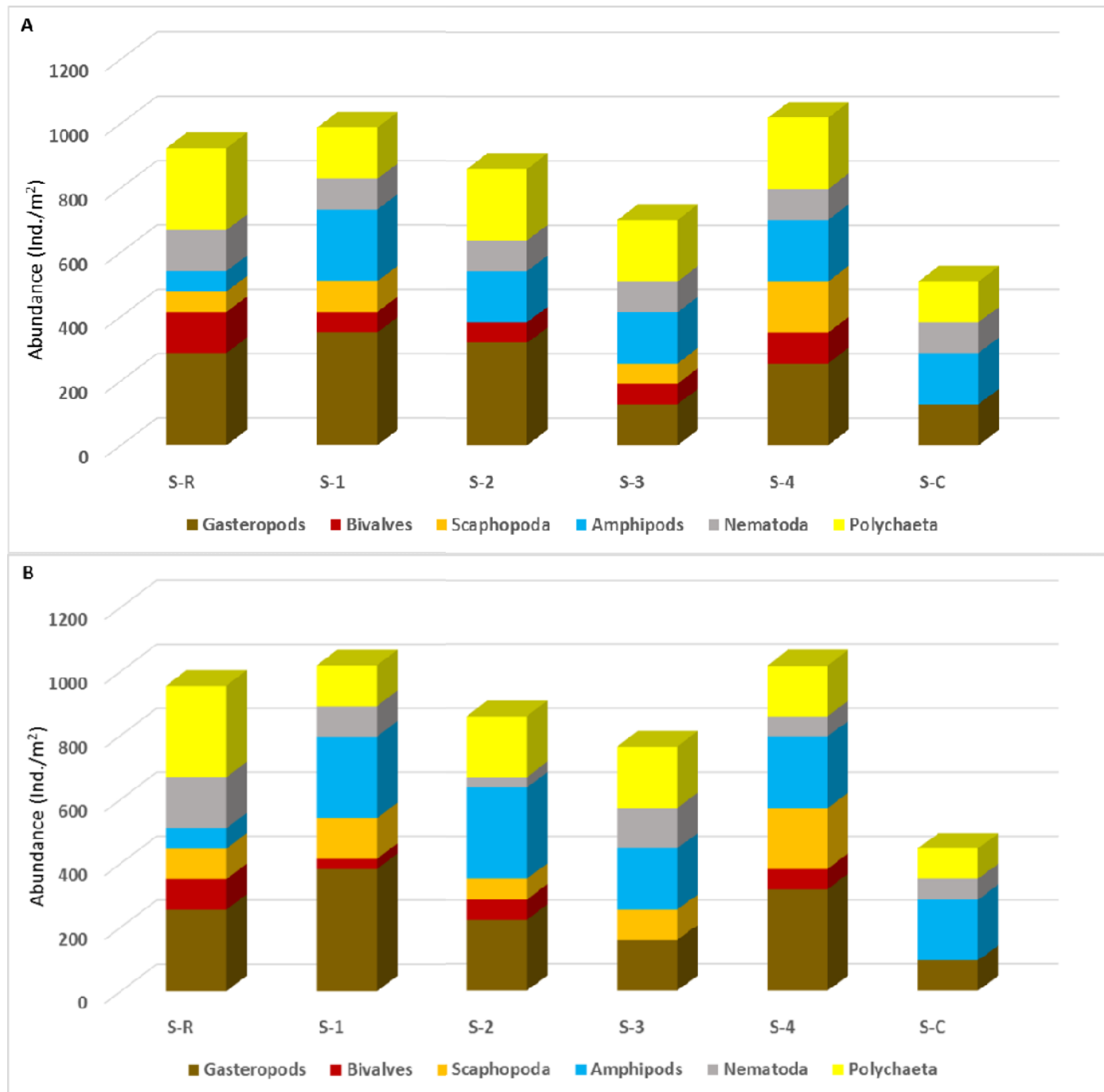

Fig. 4. Abundance values (individuals $/ \mathrm{m}^{2}$ ) of macro-benthic in sampling stations (with A graph showing 2013 results and B graph showing 2016 results).

Statistical analysis performed with ANOVA test did not shown a significant difference in terms of groups individuals between sampling stations both in 2013 and in 2016; Gastropods $(\mathrm{P}<0.05 ;$ d.f. $=1 ; \mathrm{F}=0.0085)$, Bivalves $(\mathrm{P}<0.05 ;$ d.f. $=1 ; \mathrm{F}=1.2816)$, Amphipods $(\mathrm{P}<0.05$; d.f. $=1 ; \mathrm{F}=1.2439)$, Nematoda $(\mathrm{P}<0.05 ;$ d.f. $=1 ; \mathrm{F}=0.3014)$, Polychaeta $(\mathrm{P}<0.05$; d.f. $=1 ; \mathrm{F}=0.4079)$. The number of organisms were not significantly different between stations in both years $2013(\mathrm{P}<0.05 ;$ d.f. $=5 ; \mathrm{F}=0.8366)$ and $2016(\mathrm{P}<0.05$; d.f. $=5$; $\mathrm{F}=0.8602$ ).

\section{Discussion}


According to the recorded data of the present study, most recorded results are nonsignificantly different from reference station in terms of physicochemical parameters and macro-benthic organisms. Moreover, these results seemed to be within the acceptable environment limits and could allow to say that a fish farm located in opened bay characterised by high hydrodynamic is well integrated in its local environmental with no significant impacts.

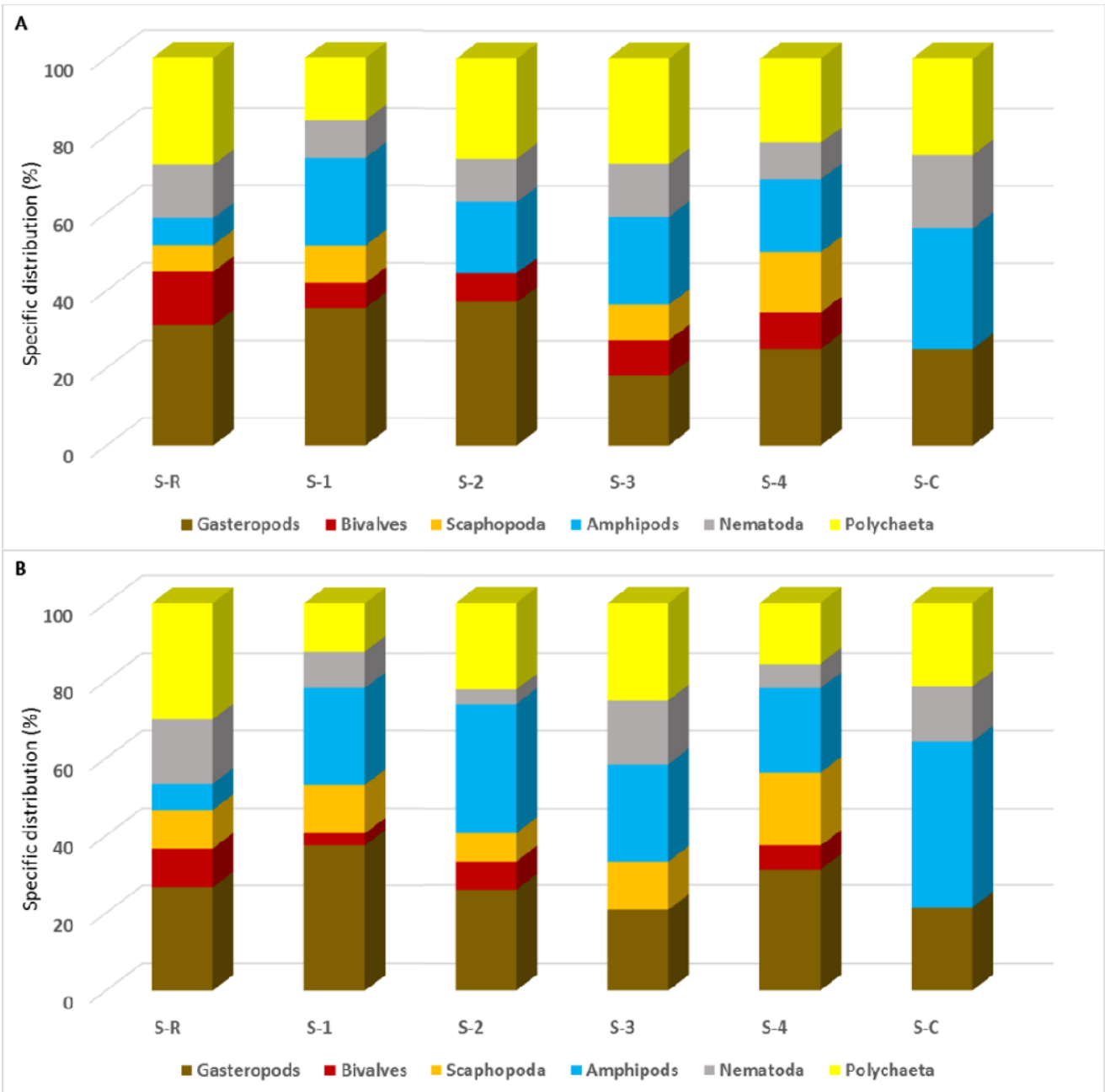

Fig. 5. Specific distribution proportion (\%) of macro-benthic in sampling stations (with A graph showing 2013 results and B graph showing 2016 results).

Actually, concerning TOC values, they did not exceed $1.87 \%$ in all sampling stations, comparing with results reported by [28], based on data collected from 951 stations in 7 coastal regions in 3 different continents. They reported there was no stress for communities associated with TOC concentrations $<1 \%$, while stress was severe at TOC concentrations $>3.5 \%$. In our study, all sampling stations, including reference station located at a distance of $500 \mathrm{~m}$ from farm limit, showed TOC values lower than $2 \%$. These results are also lower than those obtained by some authors for fish farms located in some Mediterranean areas, such as [29] whose obtained TOC values of $4.7 \%$ at a distance of $0 \mathrm{~m}$ from seabass and seabream breeding cages, which decreased to $3.14 \%$ and $3.01 \%$ moving away from the farm respectively at $5 \mathrm{~m}$ and $25 \mathrm{~m}$. 
Furthermore, in Jinhae Bay (in Korea), [30] reported that, for a mono-aquaculture of Pacific oysters, TOC percentages were ranged between $1.97 \%$ and $4.15 \%$, while [31] reported that, in six rearing seabream and seabass sites in the Aegean and Ionian seas (eastern Mediterranean Sea), the TOC percentage varied between 1\% and 5\% and remained included between $1 \%$ and $3 \% 50 \mathrm{~m}$ far from cages. In the present study, TOC values in sampling stations are not significantly different from the reference station's ones and did not exceed $1.87 \%$; it is lower than TOC values reported by [29]. It does not affect benthic community, while a medium TOC values have a visible change on the total abundance of the macro-benthic fauna.

However, in the other side, [32] recorded, a TOC percentage ranged between $0.35 \%$ and $0.68 \%$ in an integrated multi-trophic aquaculture farm in Sanggou Bay (China). They concluded that these low percentages of TOC and also other nutrient fluxes were impacted by the oxidation degree at the different stations.

Concerning OM, all sampling stations, including reference station located at a distance of $500 \mathrm{~m}$ from farm limit, showed values ranging between $0.96 \%$ and $3.2 \%$. [33] have studied the background effects of organic waste from seven Norwegian fish farms and they have obtained values ranged from 15 to $47 \%$ while in our case OM values are lower than $3.5 \%$. These results could be considered as a good indicator of the normal level of OM in fish farm in the local opened bay.

In case of Nitrogen, [34] found $0.28 \%$ before farming activity in sea trout cages (in Faroe Islands) and afterwards $0.57 \%$ during the farming period. Comparing to these results, Nitrogen percentages obtained in our case study appear to be in the same levels, except for station 4 where the recorded percentage is a little bit high $(2.83 \%)$.

Regarding Carbon, results reported by [27, 35] showed a potential Carbon releasing values which were higher than those obtained in the present case study. These results could be explained taking into consideration the M'diq fish farm production capacity which does not exceed 200 tons per year. This farm is smaller than the ones studied by [27, 35]. Comparatively, this resulted in low nutrients discharges. In addition, the current state in the present studied area is very important and disperse the released nutrients far away from the local fish farm.

In [35] study, the founding fluxes of Carbon were ranging from 8.90 to $54.24 \mathrm{~g}$ dry weight $\mathrm{m}^{-2} \mathrm{~d}^{-1}$; however, the determined deposition fluxes were ranging between 3.44 and $20.96 \mathrm{~g}$ of carbon per $\mathrm{m}^{2}$ per day, taking in consideration that carbon contents in feed and faeces was respectively $49.6 \%$ and $27.7 \%$ [36]. It is assumed that the deposition factor may be $30 \%$ of the founding fluxes. In our case, measured data of $\mathrm{C}, \mathrm{N}$ and $\mathrm{P}$ in sediment, obtained in 2013 and 2016, had no significant difference between these two years and were very low comparing to others Mediterranean fish farm. The estimated potential released values did not affect $\mathrm{C}, \mathrm{N}$ and $\mathrm{P}$ content in local sediment because of the importance of the local tidal current in the dispersion of dissolved discharges and also the importance of the population of wild fish populated around the cages in the consumption of uneaten feed.

According to [37], excess feed requires a different probability distribution for settling velocity, generally with much higher mean value compared to the faecal pellets. For example, [38] examined organic wastes around their studied fish farm in the Slovenian part of the Adriatic and have found mean settling velocity of faecal pellets and excess feed of $0.64 \pm 0.05 \mathrm{~cm} / \mathrm{s}$ and $5.7 \pm 0.15 \mathrm{~cm} / \mathrm{s}$, respectively. Similarly, [39] consider that appropriate range for settling velocity of focal pellets and excess feed is $2-4$ and $6-12 \mathrm{~cm} / \mathrm{s}$, respectively.

The environmental impact on a given aquaculture site depends mainly upon the farm's size and its production and the local hydrodynamic conditions and the site's topography. Results showed there is a maintain of satisfactory environmental conditions in and around the studied fish farms. 
The effects of organic matter and nutrients enrichment on benthic communities are depending on each site location and its specific conditions. For example, in salmon farming area, studied by $[33,40,41,42]$ the recorded data gave similar results regarding macrofaunal succession but revealed large differences regarding spatial extent of the impacts.

In general speaking, little information was known on fish farming impacts in the Mediterranean [43], where marine fish farming, particularly sea bream (Sparus aurata) and sea bass (Dicentrarchus labrax) farming, has been grown exponentially during the last period of more 30 years. Mediterranean marine environment has typical characteristics that might result in considerable differences when compared with patterns induced by salmon industry [44]. However, it worth a lot to say that some previous studies curried out in the Mediterranean have addressed some fish farming impacts on different local environment components, such as impact on water column chemistry and parasites [45], effect on nutrients and plankton (46), dynamics of sediment accumulation beneath cages [47] and recovery process of benthos after cessation [48]. The low culture biomass and the high benthic abundance combined with the important marine biodiversity, are key factors in reducing organic content in sediment. Tidal regime and current state could affect the dispersion of the organic and inorganic material and may reduce values of the studied parameters near fish farm cages such as the present studied case.

The results of the present study showed important findings highlighted in two sampling periods spaced with three years each other. The studied parameters, such as TOC, OM and macro-benthic abundance have then been important parameters to evaluate the effect of fish farm on its exploited ecosystem, using some available environment parameters knowledge (such as current velocity, current direction and frequency, distance from the rivers, adaptive fish density, good fish farming husbandry). Even if the studied parameters have shown a non-significant difference from the reference station, which is almost $500 \mathrm{~m}$ far from fish farm site, it seems necessary to recommend the extension the study duration and increase number of sampling stations and also sampling frequency (dates) according to the seasons. This would allow to refine more the present study and to seek to for understanding the mechanism that governs the interaction of this activity and its local conditions environment and to provide relevant information that can be useful for the local fish farm which has a wish to increase its production capacity in the future.

\section{Conclusion}

The main problem in fish cages culture, particularly the intensive mono or polyculture ones using carnivorous species, is generally considered to be related to the amount of released waste from the farm, mainly as uneaten feeds and faeces.

The present study has shown that M'diq fish farm has a very weak effect on local marine environment, particularly in the vicinity and surrounding area of its cages. Taking into consideration local conditions and the effects of different feeding practices, these finding could support a sustainable management of this farm and even its extending strategy (if needed). Actually, this study has allowed to gather preliminary information on how the local farm site interacts with its ecosystem with no significant negative impacts and could further be extended both in time and in space, mainly in terms of production capacity increase, farming space enlargement and cultured species diversification. It is obvious that the environmental impacts depend on the amount of food given to fishes, the mode of feeding, the fish density in cages, the annual production and the years of farming operation. The local hydrology and geomorphology are suitable factors for environmental quality preservation. Then, the location of the studied fish farm in opened bay is the most important aspect and no eutrophication phenomenon could be happened. Sediment beneath fish cages and in surrounding area was not significantly enriched in nutrients nor in organic 
carbon. However, simulated organic matter fluxes could be used in the framework of a suitable model of potential changes in sediment, in order to predict the evolution of the biogeochemical variables of sediment under different scenarios of organic matter deposition, depending on the development strategy of the local aquaculture activity and the evolution of environment conditions.

The sustainability of this fish-farming in operation rely then on the quality of its local environmental. This study has provided an important information about the accurate state of this local fish farm and could then give a reflection basis for a suitable extending production strategy. It is obvious that investment decision for harmonious development of fish farming should be decided taking into consideration an integrated management, using methods such as environmental impact assessment and risk assessment, in addition to economic evaluation, vulnerability assessments, resource accounting, cost-benefit analysis and outcome-based monitoring.

\section{References}

1. FAO, The State of World Fisheries and Aquaculture 2016: contributing to food security and nutrition for all. Rome (2016)

2. H.E. Froehlich, R.R. Gentry, M.B. Rust, D. Grimm, B.S. Halpern, PLoS ONE 12(1): e0169281(2017)

3. D. Whitmarsh, P. Wattage, European Environment. 16: 108-121 (2006)

4. R.H. Findlay, L. Watling, L.M. Mayer, Estuaries, 18: 145-179 (1995)

5. L. Guillou, C. Alves-de-Souza, R., Siano, H., González, Microbiology Today 37: 9295 (2010)

6. MAPA (Ministerio de Agricultura, Pesca y Alimentación), La Gestión Medioambiental en la Acuicultura Española. Ediciones Mundi-Prensa, (2002)

7. F. Aguado, Impacto ambiental de los sistemas piscícolas marinos: la acuicultura en jaulas flotantes. Series De Química Oceanográfica. Serie I, Monografías 1, 35-83 (2001)

8. N. Preston, P. Rothlisberg, Aquaculture environmental impacts, in Proceedings of the National Outlook Conference 29th February-2nd March Volume 1, Natural Resources, ABARE (Canberra), (2000)

9. A. Dosdat, Environmental impact of aquaculture in the Mediterranean: Nutritional and feeding aspects, in Uriarte A. (ed.), Basurco B. (ed.), Environmental impact assessment of Mediterranean aquaculture farms, Cahiers Options Méditerranéennes, CIHEAM Zaragoza, 55, 23-36 (2001)

10. U.C. Barg, D.M. Bartley, A.G.J.Tacon, R.L. Welcomme, Aquaculture and its environment: a case for collaboration, in Hancock, D.A., Smith, D.C., Grant, A., Beumer, J.P. (Eds.), Developing and Sustaining World Fisheries Resources, CSIRO Publishing, Australia, 462-470 (1997)

11. R. Boaventura, A.M. Pedro, J. Coimbra, E. Lencastre, Environmental Pollution 95 (3), 379-387 (1997)

12. B.A. Costa-Pierce, Environmental impact of nutrients from aquaculture: towards the evolution of sustainable aquaculture systems, in Baird, D.J., Beveridge, M.C.M., Kelly, L.A., Muir, J.F. (Eds.), Aquaculture and Water Resource Management, Blackwell Scientific, (1996) 
13. M.C.M. Beveridge, M.J. Phillips, R.M. Clarke, A quantitative and qualitative assessment of wastes from aquatic animal production, in Burne, D.E., Tomasso, J.R. (Eds.), Aquaculture and Water Quality, The World Aquaculture Society, (1991)

14. H., Nhhala, B., Abdellaoui, E, Talbaoui, Morocco: country report, in S., Cataudella, D., Crosetti, F., Massa (eds), Mediterranean coastal lagoons: sustainable management and interactions among aquaculture, capture fisheries and the environment, Studies and Reviews, General Fisheries Commission for the Mediterranean, FAO, Rome, (2015)

15. S. Merinero, S. Martínez, A. Tomás-Vidal, M. Jover, AquaTIC: revista electrónica de acuicultura, 23, 1-19 (2005)

16. J. Lakhdar-Idrissi, A. Orbi, F. Zidane, K. Hilmi, F. Sarf, Caractérisation physicochimique de la Baie de M'diq en relation avec l'activité aquacole. Bulletin Institut Scientifique Rabat, Section Sciences de la Vie, 23, 65-70 (2001)

17. D. Nachite, Le développement touristique du littoral de la région Tanger-Tétouan : une évolution vers des scenarios non désirables, in S. DominguezBella, A. Maate, (Eds.), Geología y geotourismo en la orilla sur delEstrecho de Gibraltar, MCN-UCA, Cadiz, Spain (2009)

18. J.C. Bertheses, N. Tesson, Observations hydrologiques sur la Sebkha Bou Areg (lagune de Nador), Travaux et documents, Bulletin de l'Instit Scientifique des Pêches Maritimes, 24, Morocco(1978)

19. A. Orbi, J. Lakhdar-Idirissi, K. Hilmi, F. Sarf, Etude hydrodynamique (courantologique) dans la baie de M'Diq, Travaux et Documents, INRH, 104: 80 Morocco(1997)

20. A. Aminot, and M. Chaussepied, Manuel des analyses chimiques en milieu marin, CNEXO, Éditions Jouve, 395 pages, Paris, France (1983)

21. G. Yucel-Gier, F. Kucuksezgin, F, Kocak, Aquaculture Research, 38, 256-267 (2007)

22. N. Neofitou, D. Vafidis, S. Klaoudatos, Aquaculture Environment Interactions, 1, 95105 (2010)

23. P. Di Marco, T. Petochi, G. Marino, A. Priori, M.G. Finoia, P. Tomassetti, B.M. Poli, Aquaculture, 471, 92-105 (2017)

24. P. Bellair, C., Pomerol. Éléments de géologie, in A. Colin (Ed.), Géologie, 526 pp., Paris, France (1977)

25. A. Walkley, I.A. Black, Soil Science, 37, 29-37 (1934)

26. B., Dabin, Application des dosages automatiques à l'analyse des sols, CahierOrstom, série Pédologie, III (4), 335-366 (1965)

27. D. Brigolin, V. Meccia, C. Venier, P. Tomassetti, S. Porrello, R. Pastres, Aquaculture Environment Interactions 5, 71-88 (2014)

28. J. Hyland, L. Balthis, I. Karakassis, P. Magni, A. Petrov, J. Shine, R. Warwick, Marine Ecology Progress Series, 295, 91-103 (2005)

29. D. Brigolin, F. Pranovi, S. Kholeif, K. Abdelsalam, R. Pastres, Regional Studies Marine Science, 7, 129-135 (2016)

30. J.H. Hyun, S.H. Kim, J.S. Mok, J.S. Lee, S.U. An, W.C. Lee, R.H. Jung, Marine Pollution Bulletin, 74(1), 187-198 (2013)

31. C.J. Cromey, H. Thetmeyer, N. Lampadariou, K. Black, J. Kögeler, I. Karakassis, MERAMOD: Aquaculture Environment Interactions, 2(2), 157-176 (2012).

32. Z. Ning, S. Liu, G. Zhang, X. Ning, R. Li, Z. Jiang, J. Zhang, Aquaculture Environment Interactions, 8, 221-232 (2016). 
33. P. Kupka-Hansen, K. Pittman, A. Ervlk, Organic waste from marine fish farms-effects on the seabed, in T. Makinen, (ed), Marine aquaculture and environment, Nordic Councilof Ministers, Copenhagen, Nord 105-119 (1991)

34. G. á Norði, R. Glud, E.Gaard, K. Simonsen, Marine Ecology Progress Series, 431, 223-241 (2011)

35. M. Jusup, J. Klanjšček, D. Petricioli, T. Legović. Ecological Modelling, 220(19): 24072414 (2009)

36. D. Brigolin, R. Pastres, T.D. Nickell, C.J. Cromey, D.R. Aguilera, P. Regnier, Marine Ecology Progress Series, 388, 63-80 (2009)

37. M. Jusup, S. Geček, T. Legović, Ecological Modelling, 200, 459-466 (2007)

38. V. Malačič, J. Forte, Annales Histoire Sciences Sociales, 13, 3-8(2003)

39. A.M. Doglioli, M.G. Magaldi, L. Vezzulli, S. Tucci, Aquaculture, 231, 215-235 (2004)

40. J.R. Brown, R.J. Gowen, D.M. McLusky, Journal of Experimental Marine Biology and Ecology, 109(1), 39-51 (1987)

41. B.D.S. O'Connor, J. Costelloe, B.F. Keegan, D.C. Rhoads. Marine Pollution Bulletin, 20(8), 384-390 (1989)

42. D.P., Weston. Marine Ecology Progress Series,61, 233-244 (1990)

43. B. Munday, A. Eleftheriou, M. Kentouri, P. Divanach. The interactions of aquaculture and the environment: A bibliographical review. Commission of the European Communities. Dir. Gen. for Fisheries, Brussels, 325 p. (1992)

44. I. Karakassis, E. Hatziyanni, Marine Ecology Progress Series,203, 247-253 (2000)

45. S. Papoutsoglou, M.J. Costello, E. Stamou, G. Tziha. Aquaculture Research, 27, 25-34 (1996)

46. P. Pitta, I. Karakassis, M. Tsapakis, S. Zivanovic, Hydrobiologia 391: 181-194 (1999).

47. I. Karakassis, M. Tsapakis, E. Hatziyanni. Marine Ecology Progress Series,162, 243252 (1998)

48. I. Karakassis, E. Hatziyanni, M. Tsapakis, W., Plaiti. Marine Ecology Progress Series, 184, 205-218 (1999) 